\title{
Brazilian Organoclays as Nanostructured Sorbents of Petroleum-Derived Hydrocarbons
}

\author{
Kleberson Ricardo de Oliveira Pereira ${ }^{a *}$, Rosângela Abdala Hanna ${ }^{\text {a }}$ \\ Marilda Mendonça Guazzelli Ramos Vianna ${ }^{\text {a }}$ Carolina Afonso Pinto ${ }^{\text {a, }}$ \\ Meiry Gláucia Freire Rodrigues ${ }^{\mathrm{b}}$,Francisco Rolando Valenzuela-Diaz ${ }^{\mathrm{a}}$ * \\ ${ }^{a}$ University of São Paulo/Polytechnic School \\ Av. Prof. Luciano Gualberto, Travessa 3, 380, 05508-900 São Paulo - SP, Brazil \\ ${ }^{\mathrm{b}}$ Federal University of Campina Grande \\ Av. Aprígio Veloso, 882, 59109-970 Campina Grande - PB, Brazil
}

Received: October 29, 2003; Revised: December 6, 2004

\begin{abstract}
Organophilic clays were prepared using a bentonite from the town of Boa Vista, state of Paraíba, Brazil, and a quaternary ammonium salt (Genamin CTAC-50). The materials obtained were characterized by X-ray diffraction and infrared spectroscopy. The results showed a good gasoline, toluene, diesel fuel and kerosene adsorbing capacity.
\end{abstract}

Keywords: organoclays, nanostructured, adsorption

\section{Introduction}

Smectitic clays, also known as bentonites and used in a variety of industrial applications, are the most widely utilized and most interesting group of clay minerals. However, their real potentialities can only be developed by subjecting them to chemical treatments. Areas polluted by organic compounds are of great concern in terms of environmental control. Several types of sorbent materials have been studied to remediate these areas. Among these materials, organoclays obtained from smectitic clays and quaternary ammonium salts - containing at least a 12-carbon chain between their layers - represent a promising material.

Areas contaminated by petrochemicals represent a common and serious environmental problem. According to the EPA (Environmental Protection Agency) databank - BFSS, Bioremediation in the Field Search System, petrochemical products are responsible for $65 \%$ of groundwater contamination in the US ${ }^{1}$.

Leakages from underground or superficial fuel reservoirs occur due to pipe failures or corrosion. These fuel leakages can cause environmental pollution, groundwater contamination, diseases and safety problems since they can reach pluvial galleries and sanitary sewers.

Natural clays containing metals as the exchange cations are not good adsorbers for removing neutral organic molecules because these types of clay have a hydrophilic character which is induced by the metallic cation ${ }^{2}$. Organic molecules are hydrophobic, so they display no affinity with the hydrophilic surfaces of clay. However, the hydrophilicity of clays can be transformed into hydrophobicity when the exchange inorganic cations are replaced by quaternary ammonium cations in the form of $\left[\left(\mathrm{CH}_{3}\right)_{3} \mathrm{NR}\right]^{+}$or $\left[\left(\mathrm{CH}_{3}\right)_{2} \mathrm{NRR}^{\prime}\right]^{+}$. This replacement results in organophilic clays. The organophilic properties of these modified clays reduce the hydration of organic cations when compared with exchange inorganic cations ${ }^{3}$.

Several organophilic clays have proved highly efficient in removing neutral organic contaminants from water and can be used, for example, to treat contaminated water, line waste reservoirs, treat industrial wastes and adsorb oil and fuel spills ${ }^{4-6}$.

\subsection{Organophilic clays - literature review}

Most clay-organic compounds are obtained through bentonites, especially the American Wyoming bentonite. According to Souza Santos ${ }^{7}$, bentonites are preferred because of the small dimensions of their crystals and their high ion exchange capacity. These features allow for fast and $100 \%$ complete interchange reactions. Moreover, their interplanar expansion can be analyzed by X-ray diffraction and infrared spectroscopy.

Organophilic clays have been synthesized from the sodium form of bentonite, which is highly hydrophilic, by adding quaternary ammonium salts (containing at least twelve carbon atoms) to aqueous dispersions of sodium bentonite. These dispersions must have a high delamination grade, i.e., the lamellae must be separate and not layered in order to facilitate the introduction of organic compounds. Under such conditions, salt organic cations replace sodium bentonite cations, causing the clay to change from a hydrophilic to an organophilic form ${ }^{8-10}$.

Some organophilic clays swell in specific organic solvents. According to Laba ${ }^{11}$, the cationic molecule portion of these salts occupies the sites previously occupied by sodium cations, while the long organic chain remains intercalated in the clay's lamellae.

Several organophilic clays have been prepared and characterized in the LMPSol laboratory of the University of São Paulo's Polytechnic School, using Brazilian smectitic clay minerals ${ }^{12-14}$.

\section{Experimental}

A pale chocolate-colored polycationic bentonite from Primavera, located in the municipality of Boa Vista, state of Paraiba, Brazil, was ground to a particle size of less than $1 \mathrm{~mm}$ to prevent it from swelling in water. Its interlayer cations were then replaced by sodium according to the following procedure: an aqueous dispersion was prepared by slowly adding ground clay to distilled water under mechanical stirring. The weight of the dispersion was $400.0 \mathrm{~g}$ and the quantity of clay added was $16.0 \mathrm{~g}$. The mixture was stirred mechanically 20 minutes. A beaker was then placed on a hot plate and a concen- 
trated aqueous solution of sodium carbonate was slowly poured into it (100 meq/100 g of dried clay) under mechanical stirring and heating. The dispersion was heated to the boiling point and then allowed to cool to room temperature for 24 hours. The weight of the dispersion was corrected by adding $4.0 \% \mathrm{w} / \mathrm{w}$ water to the clay. To transform the sample to an organophilic form, a quaternary ammonium salt (Genamin CTAC-50) in a 50\% aqueous solution was slowly added (110 meq/100 $\mathrm{g}$ of dried clay) under mechanical stirring. The mixture was stirred for 20 minutes and the dispersion was left standing at room temperature for 24 hours, after which it was filtered through a Büchner funnel. The cake was dried at $60{ }^{\circ} \mathrm{C}$ for 48 hours and then ground and sieved through a 200 mesh $(0.074 \mathrm{~mm})$ sieve.

The organophilic clay and raw clays were analyzed by X-ray Diffraction (XRD) and Infrared Spectroscopy (FTIR). The XRD performed by the powder method, using a Philips X'PERT MPD diffractometer with $\mathrm{Cu}-\mathrm{K} \alpha$ radiation, $40 \mathrm{kV}-40 \mathrm{~mA}$, scan speed of $0.0202 \Theta / s$ and 2 seconds per step. FTIR was performed by the $\mathrm{KBr}$ method with a Nicolet MAGNA 560 ESPS spectrophotometer.

\subsection{Swelling test}

The swelling of the organophilic clay in organic liquids was measured in toluene, diesel fuel, kerosene and gasoline. $1.00 \mathrm{~g}$ of powder was gradually added in small portions to $50 \mathrm{~mL}$ of organic liquid contained in a $100 \mathrm{~mL}$ graduated cylinder, without stirring. After 24 hours at room temperature, the volume of the column of clay was measured, after which the dispersion was stirred with a glass rod and allowed to stand for another 24 hours. The swelling was then recorded.

\subsection{Adsorption test}

The toluene, diesel fuel, kerosene and gasoline sorption capacity was measured following a method based on the "Standard Methods of Testing Sorbent Performance of Adsorbents (ASTM F716-82 $2^{15}$ and ASTM F 726-99 $\left.{ }^{16}\right)$ ". This test gives idealized laboratory data which can be used to compare the oil adsorbing capacity of one adsorbent with another, and also gives relative cost effectiveness. It should be kept in mind that, under normal service conditions, an adsorbent will not be exposed to a sufficiently thick oil layer to become completely or rapidly saturated. This test will therefore give maximum possible capacity data and an idealized time saturation. The adsorbent sample is weighed, minimum weight of $1 \mathrm{~g}$, and the value is recorded. The test cell is filled with an initial layer of test liquid. The adsorbent is placed in a basket (a 200 mesh stainless steel basket), which is then lowered into the test cell. The adsorbent should be allowed to float freely within the test cell. After 15 minutes \pm 0.33 minutes the basket with the adsorbent is removed manually in a vertical direction and allowed to drain for 15 seconds \pm 3 seconds. A tared weighing support is placed under the adsorbent sample/mesh basket set to catch any additional drips and the entire system is weighed. All the tests are conducted in duplicate with a minimum of two runs used for calculations. Based on the data obtained, the adsorbed oil is calculated as the ratio of adsorbed oil to dry adsorbent weight.

\section{Results and Discussion}

\subsection{X-ray diffraction analysis}

Figure 1 shows the interlayer spacings of organoclays and natural clays. The experimental and natural bentonite were previously dried at $60{ }^{\circ} \mathrm{C}$.

The properties of organoclays were investigated by basal X-ray diffraction analysis. The basal spacings of the original clays were changed from $15 \AA$ to $20.6 \AA$. The organoclay AOMC displayed a greater interlayer spacing than the corresponding natural bentonite. This behavior was confirmed by Valenzuela Diaz ${ }^{10,17}$.

\subsection{Infrared curves}

The absorption of infrared radiation by clays was recorded over a range of 4000 to $400 \mathrm{~cm}^{-1}$ (Figure 2).

The natural clay showed characteristic smectitic clay mineral peaks at $472,525,800,918,1030,1636,3436$ and $3627 \mathrm{~cm}^{-11}$. The natural clay showed no intense peaks corresponding to organic matter at 1464, 2827 and $2909 \mathrm{~cm}^{-1}$. Bala ${ }^{19}$ assigned the 1464 and $2827 \mathrm{~cm}^{-1}$ peaks to the $\mathrm{CH}_{2}$ scissor vibration band and the symmetrical $\mathrm{CH}_{3}$ stretching absorption band, respectively. The $2909 \mathrm{~cm}^{-1}$ peak was assigned to the $\mathrm{CH}$ stretching band ${ }^{18}$.

The organophilic clay also showed the characteristic peaks of clay minerals, albeit of low intensity. This is an indicative of the organophilic character of the clay ${ }^{19}$. The organic matter peaks at 1480 , 2850 and $2910 \mathrm{~cm}^{-1}$ were sharper than those of the natural clay.

The $\mathrm{CH} 3, \mathrm{CH} 2$ and $\mathrm{CH}$ bands confirmed the alkylammonium intercalation in the interlayer galleries of the clay mineral, and the lower intensity of the characteristic clay mineral peaks indicated the organophilic nature of the treated clay ${ }^{19}$.

\subsection{Swelling tests}

Figure 3 shows the swelling of the organoclays.

Intermediate values (from 6 to $8 \mathrm{~mL} / \mathrm{g}$ ) were observed for the swelling in kerosene (with mixing), gasoline (with and without mixing), and diesel (with and without mixing) attesting to the organophilicity of the organoclays. The organoclay showed high swelling values in toluene with and without mixing, i.e., 10 and $11 \mathrm{~mL} / \mathrm{g}$, respectively, and a low $(5 \mathrm{~mL} / \mathrm{g})$ swelling value in kerosene (without mixing).

As can be seen, no significant increase was found when the swelling was recorded after 48 hours and after mixing.

Toluene showed the highest swelling value, which was congruent with the adsorption test.

\subsection{Adsorption tests}

The adsorption of organic compounds was studied according to ASTM F726-99. Table 1 shows the results for organoclay.

The order of organoclay adsorption capacity was toluene $>$ gasoline $>$ diesel $>$ kerosene. The data indicated that the organoclay adsorbed more gasoline (149.3\%) and toluene (158.8\%) than diesel, and more gasoline (178.1\%) and toluene (188.7\%) than kerosene.

The adsorption capacity of the organoclay was higher than that of the natural clay. The order of natural clay adsorption capacity was kerosene $>$ diesel $>$ gasoline $>$ toluene. The adsorption values were between 1.72 to $2.22 \mathrm{~g}$ hydrocarbon / g natural clay.

The data showed that the organoclay adsorbed more toluene (437.2\%), gasoline (319.8\%), diesel (65.3\%), and kerosene (44.1\%) than did the natural clay.

The organoclay adsorbed toluene and gasoline equal to about 8 times its weight. This organoclay may be used as adsorbent material for hydrocarbons.

Table 1. Results of adsorption testing

\begin{tabular}{lcc}
\hline \multicolumn{1}{c}{ Solvent } & \multicolumn{2}{c}{ Adsorption (hydrocarbon/clay- $\mathrm{g} / \mathrm{g}$ ) } \\
Natural bentonite & Experimental \\
\hline Gasoline & 2.12 & 8.90 \\
Diesel fuel & 2.16 & 3.57 \\
Kerosene & 2.22 & 3.20 \\
Toluene & 1.72 & 9.24 \\
\hline
\end{tabular}




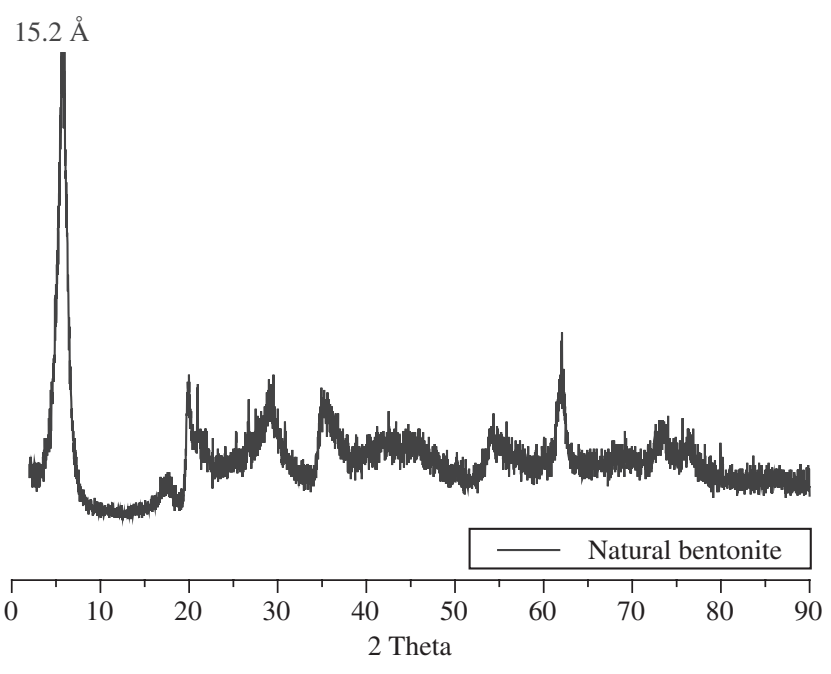

(a)

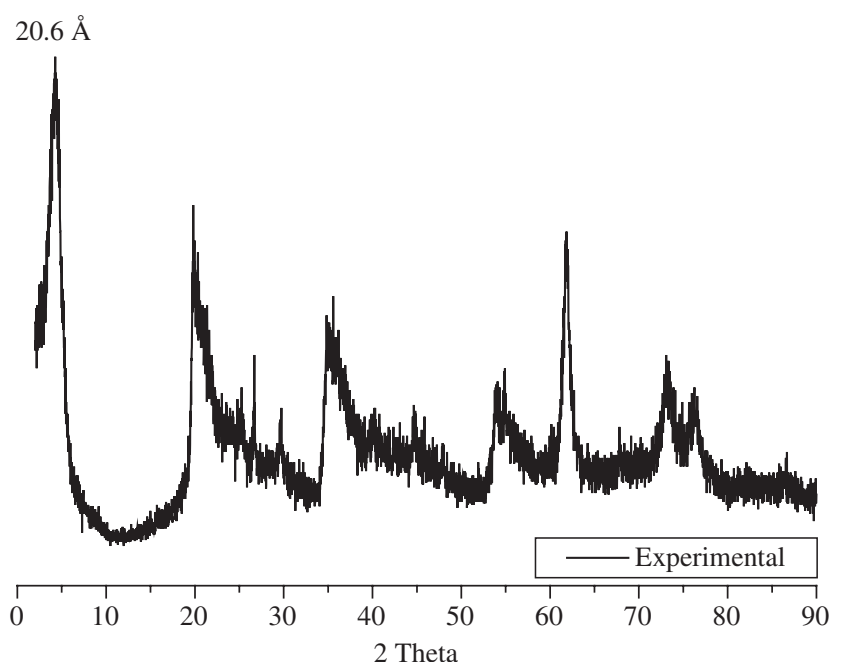

(b)

Figure 1. X-ray diffraction data: a) natural bentonite clay; b) after treatment with the quaternary ammonium salt.

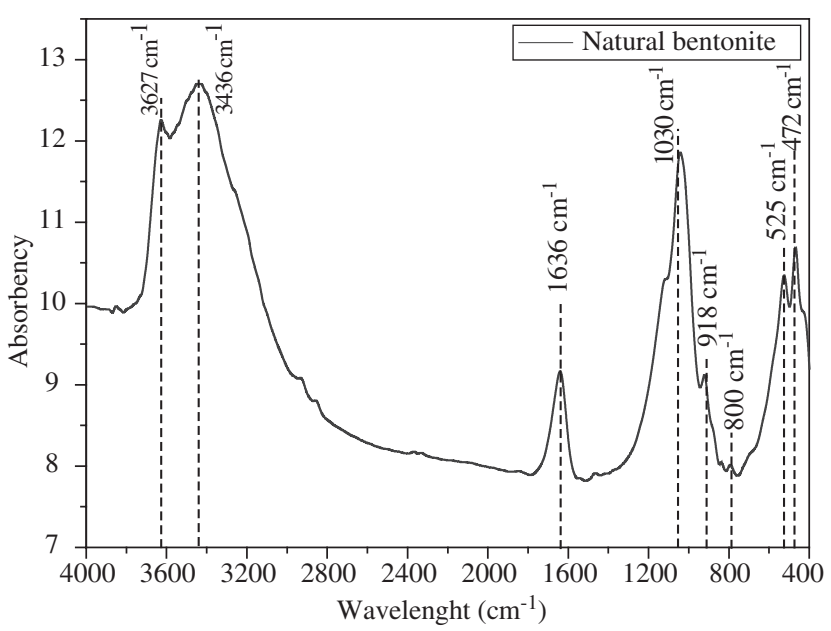

(a)

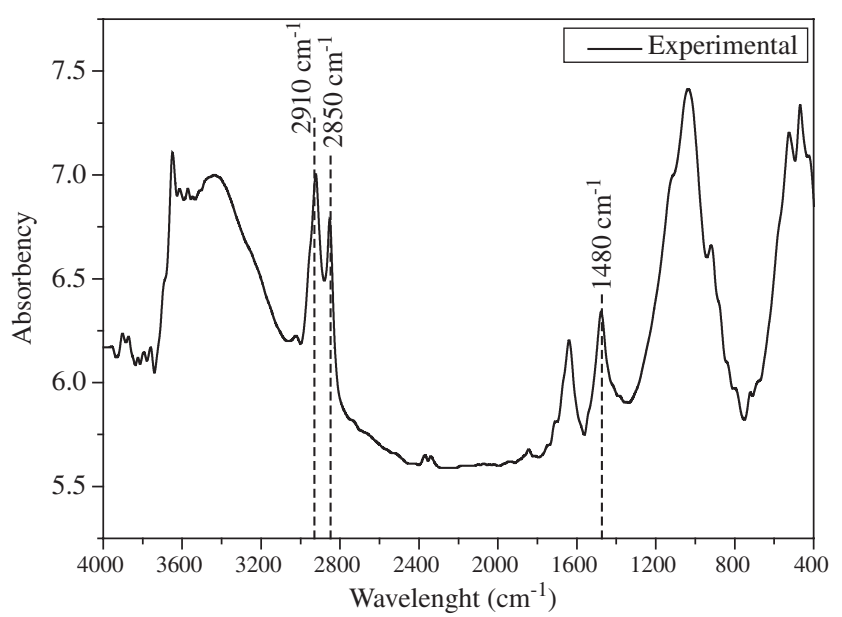

(b)

Figure 2. Infrared curves of, a) natural smectite; b) clay treated with quaternary ammonium salt.

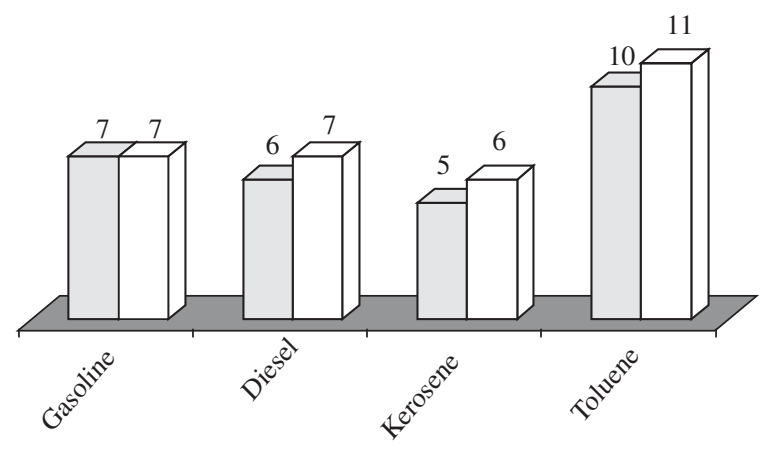

$\square$ Swelling without stirring $\square$ Swelling after stirring

Figure 3. Swelling values without and after stirring.

\section{Conclusions}

The results obtained show consistently successful synthesis of the organoclay and good adsorption properties of the smectitic clay. These findings can be considered encouraging for the use of Primavera smectite (state of Paraíba, Brazil) as an adsorbent of the hydrocarbon compounds tested here.

\section{References}

1. Environmental Protection Agency. Bioremediation in the Field Search System. Database on national and some international field applications. Version 2.0 - EPA/540/R-95/508b. Also on the Internet.

2. Zhang ZZ, Sparks DL, Scrivner NC. Sorption and desorption of quaternary amine cations on clays. Environmental Science \& Technology. 1993; 27(8):1625-31.

3. Kukkadapu RK, Boyd SA. Tetramethylphosphonium and tetramethylammonium-smectite as adsorbents of aromatic and chlorinated hydrocarbons: effect of water on adsorption efficiency. Clays and Clay Minerals. 1995; 43(3):318-23.

4. Mortland MM, Sun S, Boyd SA. Clay-organic complexes as adsorbents for phenol and chlorophenols. Clays and Clay Minerals. 1986; 34(5):581-85.

5. Boyd AS, Mortland MM, Chiou CT. Sorption characteristics of organic compounds on hexadecyltrimethylammoniun-smectite. Soil Science Society American Journal. 1988; 52(3):652-57.

6. Lee JF, Mortland MM, Chiou CT, Kile DE, Boyd SA. Adsorption of benzene, toluene, and xylene by two tetramethylammonium-smectites 
having different charge densities. Clays and Clay Minerals. 1990; 38(2):113-20.

7. Souza Santos P.de. Ciência e tecnologia de argilas. $2^{\text {nd }}$ ed. São Paulo(SP): Edgard Blücher Ltda; 1992.

8. Sharmasarkar S, Jaynes WF, Vance GF. BTEX sorption by montmorillonite organo-clays: TMPA, ADAM, HDTMA. Water air and soil pollution. 2000; 119(1-4):257-73.

9. Valenzuela-Díaz FR. Preparação ao nível de laboratório de algumas argilas esmectíticas organofilicas [thesis]. São Paulo(SP): University of São Paulo; 1994

10. Valenzuela-Díaz FR. Obtenção de argilas organofílicas partindo-se de argila esmectítica e do sal quaternário de amônio ARQUAD 2HT-75. Proceeding of the $43^{\text {th }}$ Brazilian Congress of Ceramics; 1999 Jun 2-5; Florianópolis, Brazil.

11. Laba D. Rheological properties of cosmetics and toiletries. $1^{\text {st }}$ ed. New York: Marcel Deker; 1993.

12. José CLV, Valenzuela Díaz FR, Büchler PM. Characterization and adsorption of phenol by organophilic clays. Materials Science Forum 2003; 416(418): 550-54.
13. Pinto CA. Estabilização por solidificação em cimento do resíduo do curtimento do couro contendo cromo [dissertation]. São Paulo(SP): University of São Paulo; 2001.

14. Ramos Vianna MMG. Estudo em escala de laboratório da adsorção de componentes orgânicos do vinhoto em argila organofílica [dissertation]. São Paulo(SP): University of São Paulo; 2001.

15. Standard Methods of Testing Sorbent Performance of Absorbents - Designation: F716-82 (Reapproved 1993).

16. Standard Test Method for Sorbent Performance of Adsorbents - Designation: F726-99.

17. Valenzuela Díaz FR. Preparation of organophilic clays from a Brazilian smectitic clay. Key Engineering Materials. 2001; 189(191):203-7.

18. Russel JD, Fraser AR. Infrared methods in clay mineralogy: spectroscopic and chemical determinative methods. $1^{\text {st }} \mathrm{ed}$. London: Chapman \& Hall; 1994.

19. Bala P, Samantaray BK, Srivastava SK. Synthesis and characterization of Na-montmorillonite-alkylammonium intercalation compounds. Materials Research Bulletin. 2000; 35:1717-24. 